\title{
Recent temperature trends at mountain stations on the southern slope of the central Himalayas
}

\author{
Dambaru Ballab Kattel ${ }^{1,2, *}$ and TANDong YaO $^{1}$ \\ ${ }^{1}$ Key Laboratory of Tibetan Environment Changes and Land Surface Processes, \\ Institute of Tibetan Plateau Research, Chinese Academy of Sciences, \\ PO Box 2871, 4A Datun Road, Chaoyang District, Beijing 100101, China. \\ ${ }^{2}$ Graduate University of Chinese Academy of Sciences, Beijing 100049, China. \\ ${ }^{*}$ Corresponding author. e-mail: katteldb@gmail.com
}

\begin{abstract}
Insufficient long-term in situ observations and complex topographic conditions pose major problems in quantifying the magnitude of climatic trends in mountainous regions such as Nepal. Presented here is three decades (1980-2009) of data on annual maximum, minimum and average temperature trends from 13 mountain stations on the southern slope of the central Himalayas. The stations are located at elevations between 1304 and $2566 \mathrm{~m}$ above sea level and with varied topography. Spatial analyses of the average temperature trend show warming in most of the stations. The magnitude of warming is higher for maximum temperatures, while minimum temperatures exhibit larger variability such as positive, negative or no change. These results are consistent with patterns reported in some parts of the Indian subcontinent and Upper Indus Basin, but different from conditions on the Tibetan Plateau (China), where the warming of minimum temperatures is more prominent than that of the maximum temperatures. From the temporal variations, a dramatic increase in temperature is observed in the latest decade, particularly in the average and maximum temperatures. The results from the cumulative sum chart analyses suggest that the thermal regime shifted in 1997. The dramatic enhancement of average temperature in the last decade is strongly consistent with the result of contemporary studies of the surrounding regions, where warming is attributed to an increase in anthropogenic greenhouse gases. However, as in the western Himalayas and the Upper Indus Basin, the mountain stations on the southern slope of the central Himalayas show variability in temperature trends, particularly for the minimum temperature. This inhomogeneous trend is likely ascribed to the differences in topography and microclimatic regime of the observed stations.
\end{abstract}

\section{Introduction}

Many studies (Diaz and Bradley 1997; Easterling et al. 1997; Barry 2002; Hansen et al. 2006; Bhutiyani et al. 2007; IPCC 2007) indicate a significant warming of the earth's atmosphere in the last century. Studies in some parts of the Indian subcontinent (Kothawale and Kumar 2005; Bhutiyani et al. 2007) and the Tibetan Plateau region (Liu and Chen 2000; Duan et al. 2006; You et al. 2008) have also reported a similar warming trend. A majority of previous studies (Zhang et al. 2006;

Keywords. Temperature trends; maximum temperature warming; variability; regime shift; mountain stations; central Himalayas. 
Bhutiyani et al. 2007; Yao et al. 2007b; You et al. 2008, 2010; Pal and Al-Tabbaa 2010) in those regions have also concluded that the warming trend has been accelerating in the last few decades. Many studies (Kumar et al. 2006; Duan et al. 2006; Liu et al. 2006; Bhutiyani et al. 2007; IPCC 2007; You et al. 2008) also suggest that anthropogenic greenhouse gases (GHGs) emission has become the dominant climate forcing for the warming in recent decades.

Recent studies on the Tibetan Plateau (Duan et al. 2006; Liu et al. 2006; You et al. 2008) found that minimum temperature warming is more prominent than that of the maximum. In contrast, several studies (Arora et al. 2005; Fowler and Archer 2006; Das et al. 2007; Bhutiyani et al. 2007; Pal and Al-Tabbaa 2010) covering parts of the Indian subcontinent, maximum temperature warming was observed to be more prominent in the Himalayan region and the Upper Indus Basin. A study by Duan et al. (2006), Liu et al. (2006) and You et al. (2008) on the Tibetan Plateau concluded that the asymmetric nature of maximum and minimum temperature warming is accompanied by a distinct decreasing trend of the diurnal range of air temperature. Asymmetric patterns of daily temperature changes and decreasing diurnal temperature range have been considered as signals of anthropogenic climate change. However, studies by Fowler and Archer (2006) in the Upper Indus Basin and Bhutiyani et al. (2007) in the western Himalayas found that the diurnal temperature range has been increasing. Baidya et al. (2008) also reported that the diurnal temperature range is experiencing an increasing trend at mountain stations on the southern slope of the central Himalayas. Kumar et al. (1994) and Yadav et al. (2004) suggest that the prominent warming of maximum temperature and the variability of minimum temperature trends might be caused by local forcing factors such as deforestation and land degradation.

The Nepal Himalayas is one of the largest mountainous areas of the world and commonly known as the central Himalayas. Several studies (Kadota et al. 1997; Fujita et al. 2006) have found that glaciers here have retreated considerably. The glaciers of the Nepal Himalayas are huge reservoirs of fresh water in frozen form, which maintain a perennial flow to the major rivers of Nepal and the Ganges in India (Shrestha and Aryal 2010). Changes in the hydrological cycle due to glacier melting could have large regional impacts. Many studies (Yao et al. 2007a; Ueno and Aryal 2008; Adhikari and Huybrechts 2009) suggest that rapid climatic warming is responsible for the recent glacial retreat in the Himalayas. Several studies (Kadota and Ageta 1992; Naito et al. 2001) also suggest that the reduction of snow and glacier cover in the Himalayas may also be a result of the higher rates of warming observed in this region. Most of the relevant studies on temperature trends were conducted on the Tibetan Plateau (northern slopes), the Indian subcontinent (including the western Himalayas) and the Upper Indus Basin. Studies are very limited from mountainous regions along the southern slope of the central Himalayas, Nepal. Although Shrestha et al. (1999) analysed the maximum temperature trends over Nepal during the period 1971-1994, studies on recent temperature trends over the region are still lacking.

The main objective of this study is to investigate recent annual maximum, minimum and average temperature trends from 1980 to 2009 at 13 complex mountain stations on the southern slope of the central Himalayas. Data from these stations is also compared to previously published results from surrounding regions. Possible causes of variation in temperature trends are discussed and the thermal regime shift is quantified using the cumulative sum chart.

\section{Data and methods}

Monthly mean maximum and minimum temperature data from 13 mountain stations covering the period from 1980 to 2009 were collected from the Department of Hydrology and Meteorology, Government of Nepal. Data covered an elevation range from $1304 \mathrm{~m}$ in the south to $2566 \mathrm{~m}$ in the north. The spatial distribution of stations is presented in figure 1. The elevations, geographic information, mean temperature and annual total rainfall are presented in table 1.

As a preliminary quality control, the monthly maximum and minimum temperature data series were manually inspected for all stations and for all years. Any suspicious values, for example, a maximum temperature value that is lower than the corresponding minimum temperature value, were removed. Outliers were identified through Grubbs' methods (Grubbs 1950, 1969), presented in the Appendix. In addition to determining whether the recorded values are outliers or true events, regression through the origin was performed. Consistent coolest (e.g., 1997) and warmest years (e.g., 1998, 1999 and 2009) were noticed in most of the stations during regression through the origin. The mean value of each station was then calculated and regression analysis performed with and without the values. No significant difference was found, nor was there any difference found in the mean and temperature trends. Thus, all values were kept as true events for this analysis. The Shapiro-Wilk, Lilliefors Probability and Kolmogorov-Smirnov tests show that the data series is normally distributed. 


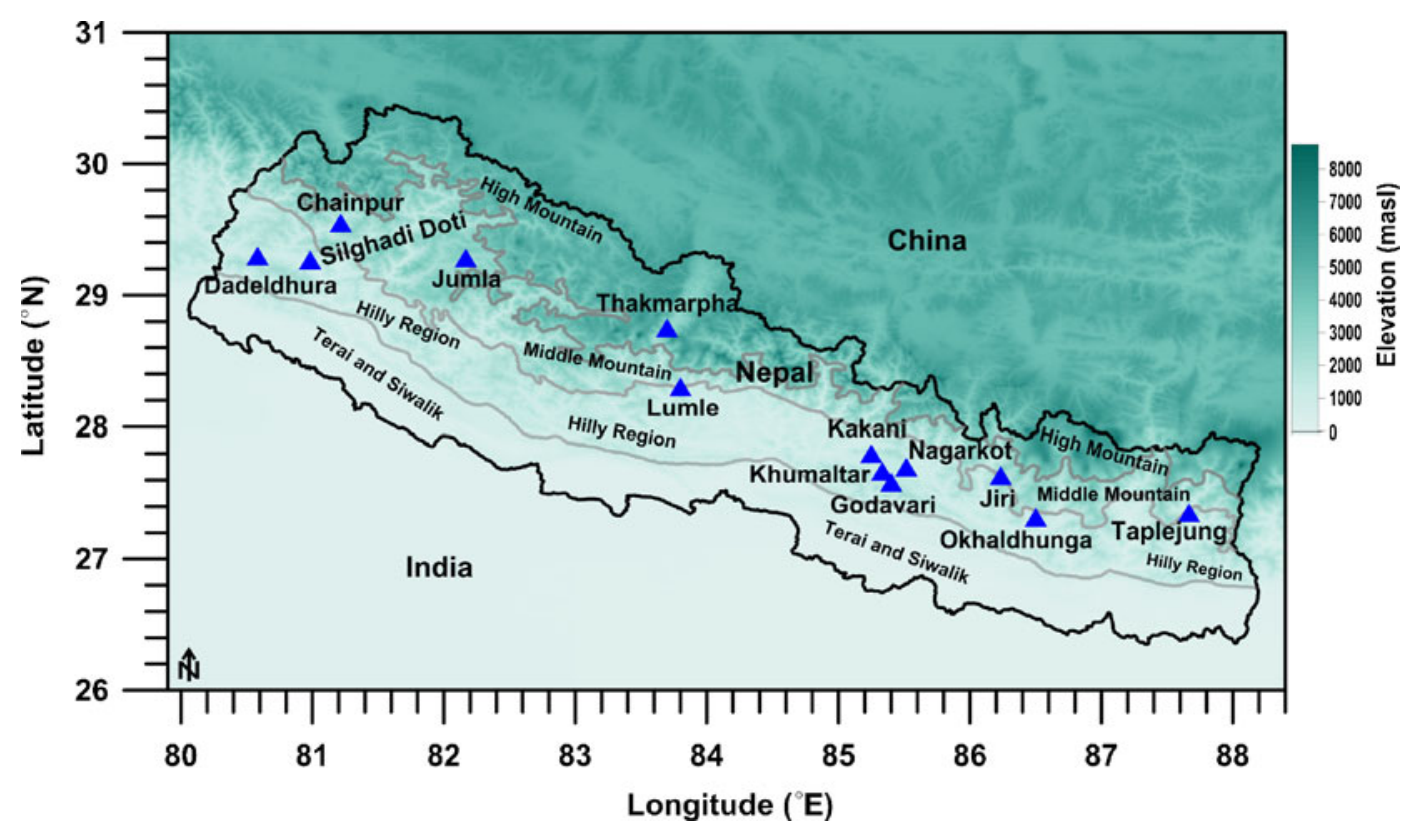

Figure 1. Spatial distribution of the mountain stations included in this study.

Table 1. Geographic information, elevation and 30-year (1980-2009) mean of maximum, minimum and average temperatures and total rainfall at mountain stations on the southern slope of the central Himalayas.

\begin{tabular}{|c|c|c|c|c|c|c|c|c|c|}
\hline \multirow{2}{*}{$\begin{array}{l}\text { Index } \\
\text { no. }\end{array}$} & \multirow{2}{*}{$\begin{array}{l}\text { Station } \\
\text { name }\end{array}$} & \multirow{2}{*}{$\begin{array}{l}\text { Latitude } \\
\left({ }^{\circ} \mathrm{N}\right)\end{array}$} & \multirow{2}{*}{$\begin{array}{l}\text { Longitude } \\
\left({ }^{\circ} \mathrm{E}\right)\end{array}$} & \multirow{2}{*}{$\begin{array}{l}\text { Elevation } \\
(\text { masl })\end{array}$} & \multicolumn{3}{|c|}{ Temperature $\left({ }^{\circ} \mathrm{C}\right)$} & \multirow{2}{*}{$\begin{array}{l}\text { Rainfall } \\
\text { (mm) }\end{array}$} & \multirow[b]{2}{*}{ Topography } \\
\hline & & & & & $T_{\max }$ & $T_{\min }$ & $T_{\text {avg }}$ & & \\
\hline 202 & Chainpur & $29^{\circ} 33^{\prime}$ & $81^{\circ} 13^{\prime}$ & 1304 & 25.87 & 12.10 & 19.00 & 1596.63 & Valley (S) \\
\hline 1029 & Khumaltar & $27^{\circ} 40^{\prime}$ & $85^{\circ} 20^{\prime}$ & 1350 & 24.39 & 11.63 & 17.99 & 1182.12 & Valley (C) \\
\hline 203 & Silghadi Doti & $29^{\circ} 16^{\prime}$ & $80^{\circ} 59^{\prime}$ & 1360 & 24.14 & 14.12 & 19.67 & 1357.90 & Slope $(\mathrm{S}-\mathrm{H})$ \\
\hline 1022 & Godavari & $27^{\circ} 35^{\prime}$ & $85^{\circ} 24^{\prime}$ & 1400 & 21.90 & 11.59 & 16.77 & 1823.12 & Valley (S) \\
\hline 1206 & Okhaldhunga & $27^{\circ} 19^{\prime}$ & $86^{\circ} 30^{\prime}$ & 1720 & 21.44 & 12.82 & 17.10 & 1759.33 & Hilltop (S) \\
\hline 1405 & Taplejung & $27^{\circ} 21^{\prime}$ & $87^{\circ} 40^{\prime}$ & 1732 & 20.76 & 11.87 & 16.36 & 1978.80 & Slope $(\mathrm{S})$ \\
\hline 814 & Lumle & $28^{\circ} 18^{\prime}$ & $83^{\circ} 48^{\prime}$ & 1740 & 20.15 & 11.97 & 16.07 & 5490.22 & Slope (S) \\
\hline 104 & Dadeldhura & $29^{\circ} 18^{\prime}$ & $80^{\circ} 35^{\prime}$ & 1848 & 20.88 & 11.32 & 16.10 & 1397.59 & Hilltop \\
\hline 1103 & Jiri & $27^{\circ} 38^{\prime}$ & $86^{\circ} 14^{\prime}$ & 2003 & 20.43 & 8.14 & 14.30 & 2345.08 & Valley \\
\hline 1007 & Kakani & $27^{\circ} 48^{\prime}$ & $85^{\circ} 15^{\prime}$ & 2064 & 19.84 & 10.77 & 15.32 & 2834.98 & Slope $(\mathrm{S})$ \\
\hline 1043 & Nagarkot & $27^{\circ} 42^{\prime}$ & $85^{\circ} 31^{\prime}$ & 2163 & 19.42 & 9.95 & 14.67 & 1827.12 & Slope (N) \\
\hline 303 & Jumla & $29^{\circ} 17^{\prime}$ & $82^{\circ} 10^{\prime}$ & 2300 & 20.79 & 4.90 & 12.85 & 819.94 & Valley (S) \\
\hline 604 & Thakmarpha & $28^{\circ} 45^{\prime}$ & $83^{\circ} 42^{\prime}$ & 2566 & 16.86 & 5.54 & 11.14 & 403.25 & Valley (N) \\
\hline
\end{tabular}

Note: The topography is classified by using the SRTM3 digital elevation model (DEM), which is retrieved from the website of the USGS. In the table, $\mathrm{C}=$ centre, $\mathrm{S}=$ south, $\mathrm{H}=$ hilltop, $\mathrm{N}=$ north.

Annual mean monthly maximum and minimum temperatures were calculated for all stations using the arithmetic mean method. Average temperature is the mean of monthly maximum and minimum temperatures.

The simple linear regression model was used to determine the monthly maximum, minimum and average temperature trends of each station. Linear regression refers to a group of techniques for fitting and studying the straight-line relationship between two variables. Therefore, the series of linear equations of each station was obtained from the following formula.

$$
Y=t X+C+e .
$$

In equation (1), $Y$ (temperature in ${ }^{\circ} \mathrm{C}$ ) is the dependent, $X$ (time) is the independent variable and ' $C$ ' and ' $e$ ' are the constant and error of regression terms, respectively. The regression coefficient ' $t$ ' is the trend in ${ }^{\circ} \mathrm{C} / \mathrm{y}$. 
Temperature trends were evaluated with the Mann-Kendall (M-K) trend test using a normal approximation method. In addition, to investigate the relationship of interannual variation of temperature between mountain stations, the Pearson product moment correlation was computed.

Cumulative sum charts (CUSUM) were plotted to examine the thermal regime shift. This technique was introduced by Page (1961). The CUSUM is generally defined as the cumulative sum (also known as control charts) of the deviations of a time series about a target value (Mansell 1997). The mean of the time series is normally taken as the target value that provides comparative information useful in analysis to find potential trend shifts as well as small and sustained changes or slow fluctuations (Mansell 1997; Hodges et al. 2003; Chen and Chen 2007; Shapiro et al. 2010).

The procedure to construct cumulative sum (CUSUM) charts consists of taking observed values of size ' $n$ ' and plotting the cumulative sums versus the data number ' $r$ '.

$$
S_{r}=\sum_{i=1}^{r}\left(x_{i}-k\right),
$$

where ' $x_{i}$ ' is the mean of the data and ' $k$ ' is the reference value. Here, ' $k$ ' is a constant used to detect positive drift in the process (Tam 2009). According to Page (1961), the plot turns upwards if the process leads to an increase above ' $k$ ' the constant. In addition, with continuous negative increments, ' $x_{i}-k<0$ ', the path of the CUSUM-chart plot will point downward indicating no positive deviation.

The statistical detection criterion in the CUSUM-chart plot is set by an alarm value, ' $h$ ', for which ' $S_{r}>h$ ' will trigger an alarm as a significant deviation from the mean. Thus, most CUSUMchart detection methods provide an estimate of ' $h$ ' for a given average run length (Tam 2009).

In our study, we have estimated the upper and lower control limits (UCL and LCL), $h=2$, standard deviations $(\sigma)$ and $k=0.5$. Therefore, in our plots, the boundary value of the upper and lower control limits lies between $\pm 2 \sigma$.

\section{Results and discussion}

\subsection{Spatial variations of temperature trends}

The spatial distribution of average, maximum and minimum temperature trends from 1980-2009 on the southern slope of the central Himalayas, Nepal, is presented in figure $2(\mathrm{a}, \mathrm{b}, \mathrm{c})$. The spatial pattern of average and maximum temperature trend in figure $2(\mathrm{a}, \mathrm{b})$ shows the greatest amount of warming for the mountain stations, while the minimum temperature trends exhibit more variation.

The regression results between temperature and time are presented in table 2 . The statistically significant warming of average temperatures range from $0.20^{\circ}$ to $0.66^{\circ} \mathrm{C} /$ decade $\left(R^{2}=8-70 \%\right)$. The result from the $\mathrm{M}-\mathrm{K}$ trend test is presented in table 3. Shrestha et al. (1999) have analysed temperature trends of 49 stations in Nepal. They found that maximum temperature trends range from $0.6^{\circ}$ to $1.2^{\circ} \mathrm{C}$ /decade for most of the mountain stations for the period 1971-1994 (23 years). Out of 49 stations, they used 11 stations as mountain sites (except Chainpur and Dadeldhura) to quantify the temperature trends on the southern slope of the central Himalayas. This 30-year temperature time series study also suggests that the greatest warming is seen in maximum temperatures. The magnitude of statistically significant warming and the proportion variation $\left(R^{2}\right)$ is also larger for the maximum temperature, which ranges from $0.26^{\circ}$ to $1.36^{\circ} \mathrm{C} /$ decade and $12 \%$ to $82 \%$, respectively (figure $2 \mathrm{~b}$ and table 2 ).

Minimum temperature trends are more variable (figure 2c). The proportion of variation $\left(R^{2}\right)$ is comparatively weaker than for the maximum temperature, which ranges from $0.3 \%$ to $62 \%$ (table 2 ). It is noted that the $\mathrm{M}-\mathrm{K}$ trend test for minimum temperature is not statistically significant for a majority of the stations (figure $2 \mathrm{c}$ and table 3 ).

\subsection{Trends of individual stations}

The interannual variations of temperature anomaly, trends and 5-year running average of average, maximum and minimum temperatures of individual stations are presented in figure $3(\mathrm{a}, \mathrm{b}, \mathrm{c})$. Anomalies were calculated subtracting the 30-year mean value from the values of individual years. Out of 13 stations, the two stations Dadeldhura $\left(t=1.36^{\circ} \mathrm{C} /\right.$ decade, $\left.R^{2}=82 \%\right)$ and Okhaldhunga $\left(t=1.29^{\circ} \mathrm{C} /\right.$ decade, $\left.R^{2}=77 \%\right)$ show a greater magnitude of warming in 1980-2009, particularly for maximum temperature (table 2). These stations are hilltop stations. Average warming at these two stations is $0.61^{\circ} \mathrm{C} /$ decade $\left(R^{2}=61 \%\right)$ and $0.66^{\circ} \mathrm{C} /$ decade $\left(R^{2}=70 \%\right)$, respectively. In contrast to the increase in maximum temperatures, Dadeldhura reveals a negative trend $\left(t=-0.14^{\circ} \mathrm{C} /\right.$ decade, $\left.R^{2}=7 \%\right)$ for minimum temperature and Okhaldhunga shows no change (table 2). The maximum and average temperature trends for both stations are statistically significant at the level of 0.001, although the trends for minimum temperatures are not statistically significant. 


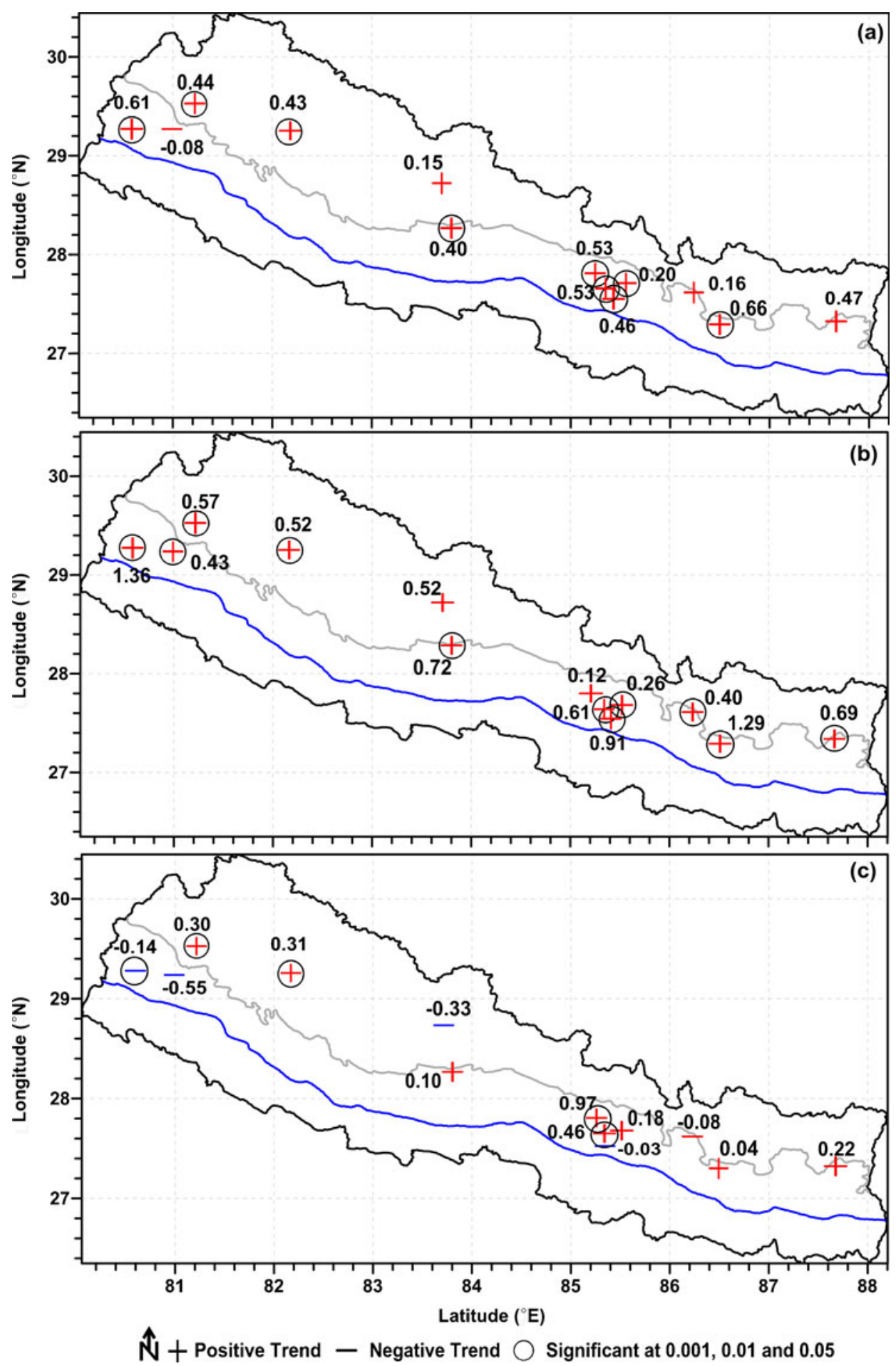

Figure 2. Spatial distribution of the trends $\left({ }^{\circ} \mathrm{C} /\right.$ decade) of (a) average, $(\mathbf{b})$ maximum and $(\mathbf{c})$ minimum temperatures.

The statistically significant higher magnitude warming is observed for a majority of the valley stations, with maximum temperature ranges from $0.40^{\circ}$ to $0.91^{\circ} \mathrm{C} /$ decade. In our study, Chainpur $\left(t=0.57^{\circ} \mathrm{C} /\right.$ decade, $\left.R^{2}=62 \%, P<0.001\right)$ is the lowest elevation station, while Jiri $(t=$ $0.40^{\circ} \mathrm{C} /$ decade, $\left.R^{2}=48 \%, P<0.01\right)$, Jumla $(t=$ $0.52^{\circ} \mathrm{C} /$ decade, $\left.R^{2}=41 \%, P<0.05\right)$ and Thakmarpha $\left(t=0.52^{\circ} \mathrm{C} /\right.$ decade, $\left.R^{2}=53 \%, P<0.09\right)$ are located at higher elevations. The two stations Khumaltar $\left(t=0.61^{\circ} \mathrm{C} /\right.$ decade, $R^{2}=67 \%, P<$ $0.001)$ and Godavari $\left(t=0.91^{\circ} \mathrm{C} /\right.$ decade, $R^{2}=$ $81 \%, P<0.001)$ are located in the central and southern parts of the Kathmandu valley. It is noted 
Table 2. Results from the regression analyses between temperature and time.

\begin{tabular}{|c|c|c|c|c|c|c|c|c|c|}
\hline \multirow[b]{2}{*}{ Stations } & \multicolumn{3}{|c|}{ Maximum } & \multicolumn{3}{|c|}{ Minimum } & \multicolumn{3}{|c|}{ Average } \\
\hline & $t\left({ }^{\circ} \mathrm{C} / \mathrm{d}\right)$ & $R^{2}(\%)$ & MS & $t\left({ }^{\circ} \mathrm{C} / \mathrm{d}\right)$ & $R^{2}(\%)$ & MS & $t\left({ }^{\circ} \mathrm{C} / \mathrm{d}\right)$ & $R^{2}(\%)$ & MS \\
\hline Chainpur & 0.57 & 62 & 0.17 & 0.30 & 27 & 0.20 & 0.44 & 59 & 0.12 \\
\hline Khumaltar & 0.61 & 67 & 0.16 & 0.46 & 62 & 0.20 & 0.53 & 82 & 0.06 \\
\hline Silghadi Doti & 0.43 & 41 & 0.21 & -0.55 & 25 & 0.69 & -0.08 & 0.2 & 0.25 \\
\hline Godavari & 0.91 & 81 & 0.17 & -0.03 & 0.3 & 0.11 & 0.46 & 62 & 0.11 \\
\hline Okhaldhunga & 1.29 & 77 & 0.41 & 0.04 & 1 & 0.11 & 0.66 & 70 & 0.15 \\
\hline Taplejung & 0.69 & 70 & 0.15 & 0.22 & 19 & 0.16 & 0.47 & 59 & 0.12 \\
\hline Lumle & 0.72 & 53 & 0.37 & 0.10 & 5 & 0.17 & 0.40 & 49 & 0.14 \\
\hline Dadeldhura & 1.36 & 82 & 0.35 & -0.14 & 7 & 0.22 & 0.61 & 61 & 0.2 \\
\hline Jiri & 0.40 & 48 & 0.12 & -0.08 & 2 & 0.26 & 0.16 & 14 & 0.12 \\
\hline Kakani & 0.12 & 5 & 0.24 & 0.97 & 54 & 0.67 & 0.53 & 50 & 0.23 \\
\hline Nagarkot & 0.26 & 12 & 0.42 & 0.18 & 12 & 0.20 & 0.20 & 17 & 0.17 \\
\hline Jumla & 0.52 & 41 & 0.30 & 0.31 & 39 & 0.12 & 0.43 & 48 & 0.16 \\
\hline Thakmarpha & 0.52 & 53 & 0.21 & -0.33 & 18 & 0.45 & 0.15 & 8 & 0.26 \\
\hline
\end{tabular}

$t=$ temperature trends $\left({ }^{\circ} \mathrm{C} /\right.$ decade $), R^{2}=$ proportion of variation and $\mathrm{MS}=$ Residual mean square error.

Table 3. Results from the Mann-Kendall trend test evaluated using a normal approximation.

\begin{tabular}{|c|c|c|c|c|c|c|}
\hline \multirow{2}{*}{$\begin{array}{l}\text { Station } \\
\text { name }\end{array}$} & \multicolumn{2}{|c|}{ Maximum } & \multicolumn{2}{|c|}{ Minimum } & \multicolumn{2}{|c|}{ Average } \\
\hline & $P$ & $Z$ & $P$ & $Z$ & $P$ & $Z$ \\
\hline Chainpur west & $<0.001$ & 3.63 & 0.007 & 2.44 & $<0.0001$ & 3.79 \\
\hline Khumaltar & $<0.001$ & 3.86 & $<0.0001$ & 4.20 & $<0.0001$ & 4.01 \\
\hline Silghadi Doti & 0.006 & 2.49 & 0.09 & -1.32 & 0.27 & -0.62 \\
\hline Godavari & $<0.001$ & 4.09 & 0.411 & -0.22 & 0.015 & 2.18 \\
\hline Okhaldhunga & $<0.001$ & 3.77 & 0.38 & 0.30 & 0.0006 & 3.21 \\
\hline Taplejung & $<0.001$ & 4.11 & 0.37 & -0.32 & 0.089 & 1.35 \\
\hline Lumle & 0.009 & 2.35 & 0.22 & 0.79 & 0.003 & 2.77 \\
\hline Dadeldhura & $<0.001$ & 4.19 & 0.03 & -1.88 & 0.0001 & 3.62 \\
\hline Jiri & 0.001 & 3.02 & 0.22 & -0.77 & 0.17 & 0.93 \\
\hline Kakani & 0.20 & 0.85 & 0.0005 & 3.29 & 0.0001 & 3.71 \\
\hline Nagarkot & 0.005 & 2.57 & 0.10 & 1.26 & 0.01 & 2.13 \\
\hline Jumla & 0.014 & 2.19 & 0.003 & 2.75 & 0.032 & 1.85 \\
\hline Thakmarpha & 0.09 & 1.32 & 0.14 & -1.08 & 0.13 & 1.08 \\
\hline
\end{tabular}

$P=$ probability and $Z=$ test statistics.

that the minimum temperature trends for these valley stations exhibit higher variability (table 2 ).

In contrast to the valley stations, most of the stations located on a slope (except Silghadi Doti) exhibit obvious warming for both maximum and minimum temperatures, ranging from $0.12^{\circ}$ to $0.72^{\circ} \mathrm{C} /$ decade (maximum) and $0.10^{\circ}$ to $0.97^{\circ} \mathrm{C} /$ decade (minimum). For these stations located on a slope, Taplejung, Lumle, Kakani and Nagarkot, the trend test reveals a statistically significant trend only at Kakani for the minimum temperature at the level of 0.001 , and Taplejung, Lumle and Nagarkot for the maximum temperature at the level of $0.001,0.01$ and 0.001, respectively (table 3 ).
Temperature trends with respect to elevation are presented in figure 4 . Figure 4 indicates that the temperature trends at mountain stations do not show a clear relationship between elevation and warming possibly due to the small amount data in a relatively small elevation range. More consistent warming is observed for maximum temperature at all elevations, while minimum temperature trends show more variation.

\subsection{Regime shift}

The interannual variation of temperature for all mountain stations (figure 3) shows a similar pattern of succession for the negative and positive 
(a) Maximum temperature

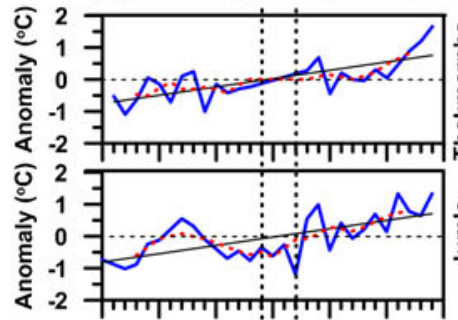

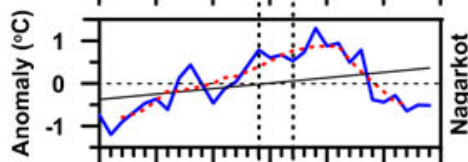

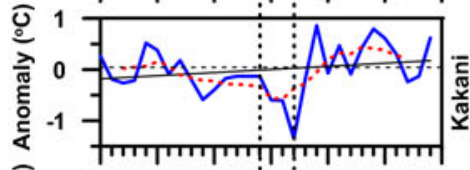

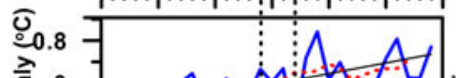

ते 0 -

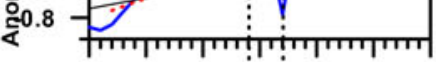

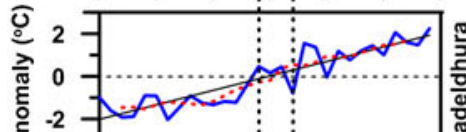

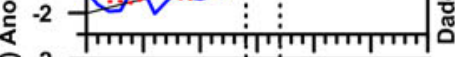

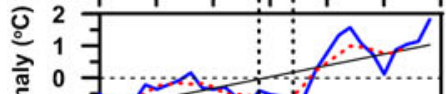

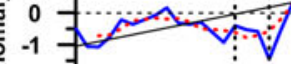

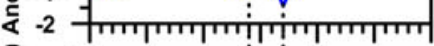

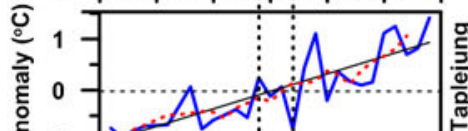

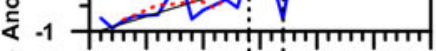

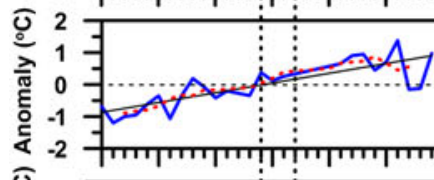

তু
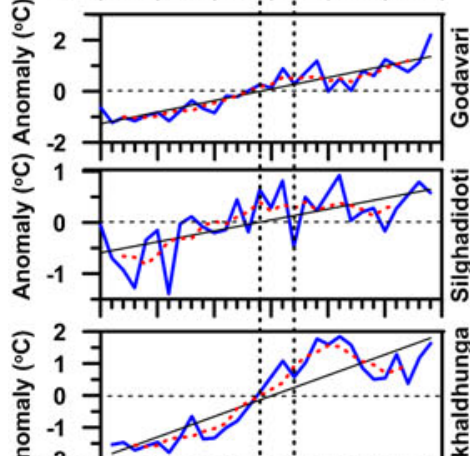

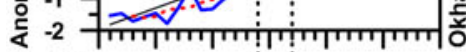

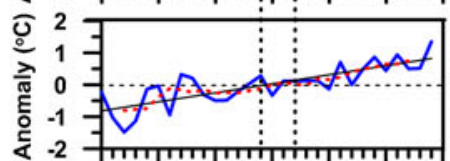

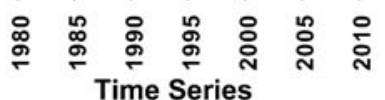

(b) Minimum temperature

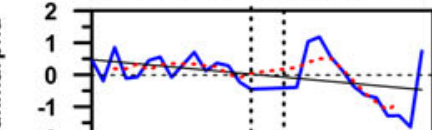

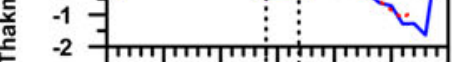

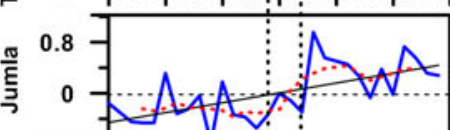

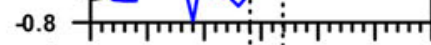
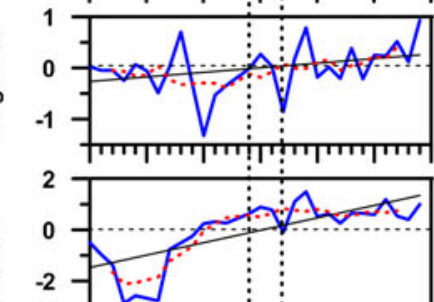

मानियागा

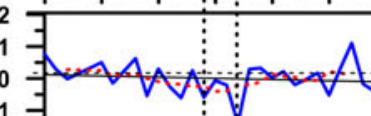

-1 -

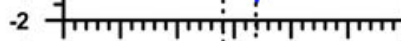

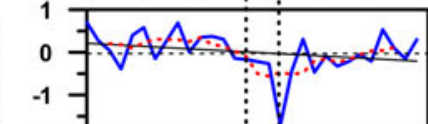

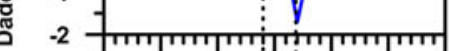

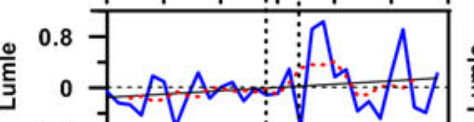

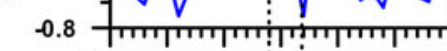
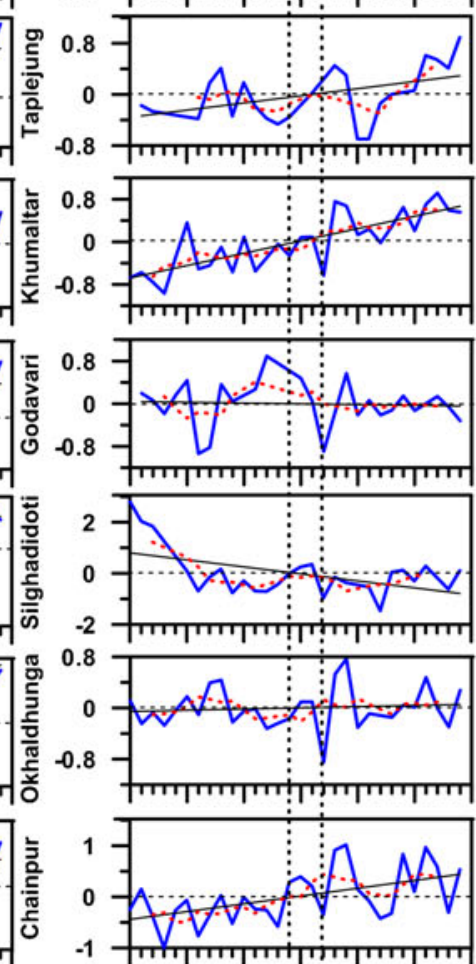

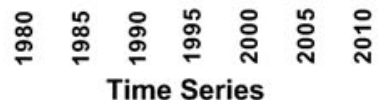

(c) Average temperature
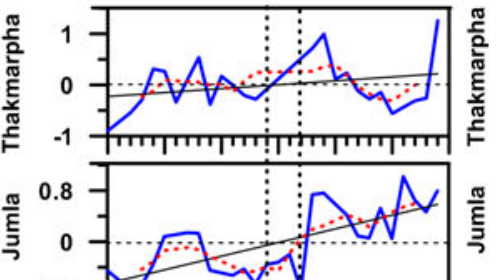

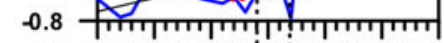
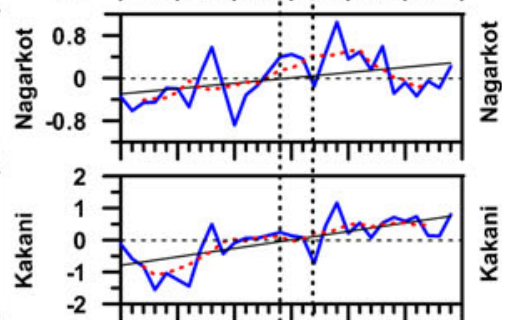

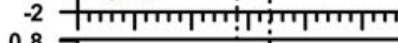

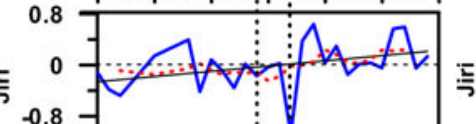

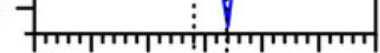
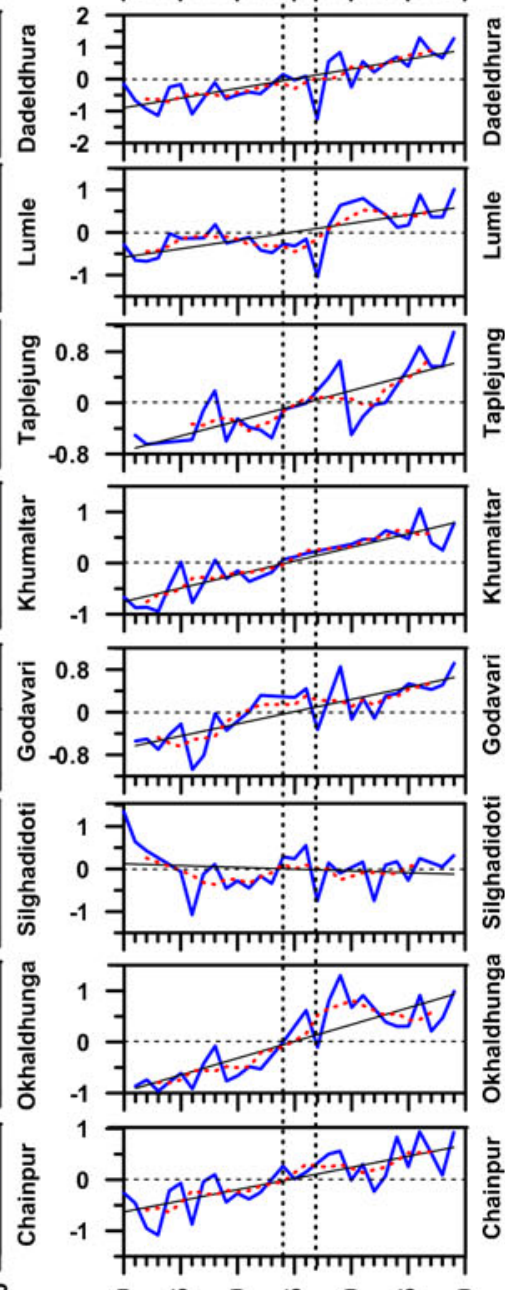

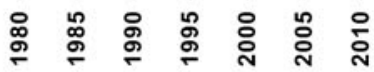

Time Series

Figure 3. Time series, trend and 5-year running average (dotted line) of (a) maximum, (b) minimum and (c) average temperatures. 


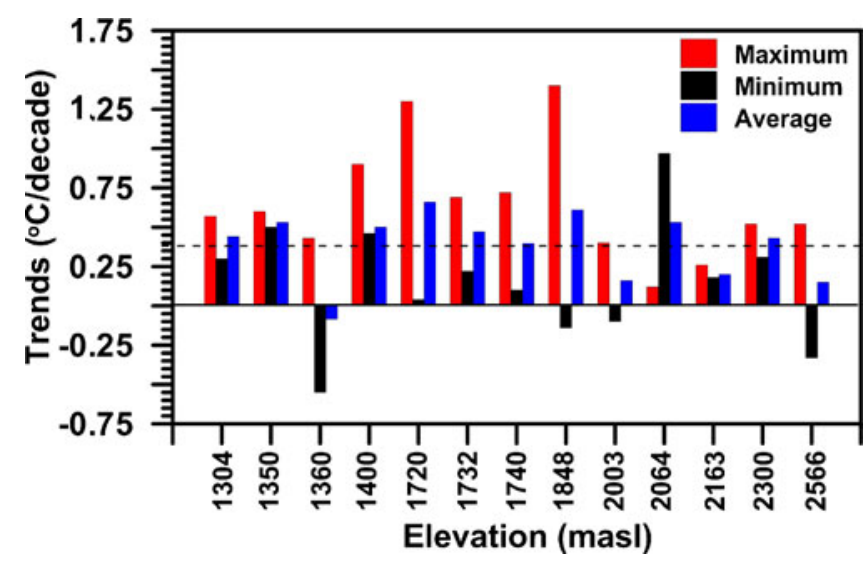

Figure 4. Distribution of temperature trends with respect to elevation.

anomalies. The positive anomaly of temperature indicates that the interannual values exceeded the mean value and the negative anomaly indicates that the values are lower than the mean value. Additionally, at most stations, a sudden change of direction appeared in 1994 and more sharply in 1997, particularly for the maximum and average temperature anomalies (figure 3a, c).

The representative charts (CUSUM) in figure 5 display the cumulative sums of the deviation of the observed maximum, minimum and average temperatures of all mountain stations. In figure 5 , the plotted points (dots) fluctuate mainly in the horizontal direction exhibiting the random variable. However, the red plotted points (squares and triangles) indicate that the observed values are beyond the $2 \sigma$ limit, exhibiting a non-random pattern of temperature variability. Mansell (1997) suggested that if the variables were distributed evenly for each year, the CUSUM would be zero throughout the period: the greater the deviation from a straight line, the greater the unevenness of variables.

A sharp regime shift is clearly apparent for maximum and average temperatures from 1997 to 2009 (figure 5a, c). Relatively similar features are found for both maximum and average temperatures of individual station CUSUM plot analyses (not shown). In addition, from 1994 until the end of the study period, trend analyses revealed a magnitude of warming that is comparatively higher than that for the period from 1980 to 1993. Thus, the segment on CUSUM charts (figure 5a, c) with an upward slope indicates a period when the temperature values tended to be above the climatic average. It is noted that the change in the slope of CUSUM charts indicates a regime shift (Shapiro et al. 2010) since 1997 at mountain stations in the study area. In contrast, the CUSUM chart does not show any such feature for minimum temperature due to the greater variability (figure $5 \mathrm{~b}$ ).

\subsection{Comparison with the surrounding region}

The average warming of the 13 mountain stations in the study area is about $0.38^{\circ} \mathrm{C} /$ decade. The magnitude of warming is greater for the maximum temperature $\left(0.65^{\circ} \mathrm{C} /\right.$ decade $)$ than for the minimum temperature $\left(0.11^{\circ} \mathrm{C} /\right.$ decade $)$. It is also reasonable to conclude that, given the discussion in subsections 3.1 and 3.2, there is more consistency in warming for the maximum temperatures in all stations than for the minimum temperatures; the minimum temperatures display higher variability such as positive, negative or no change. This result is consistent with patterns found in related research from some parts of the Indian subcontinent and Upper Indus Basin, although different from results from the Tibetan Plateau region.

Studies by Pal and Al-Tabbaa (2010) in various regions of India showed that minimum temperature changes are more variable than those of maximum temperature. Das et al. (2007) also noted both an increase and decrease in the minimum temperatures in the southern and northern regions of India with interannual variability. Moreover, Arora et al. (2005) found a falling trend in the annual minimum temperature at most stations located in the foothills of the Himalayas, India. Kumar et al. (1994) and Yadav et al. (2004) analysed a western Himalaya data series and found a marked decrease in minimum temperatures in the later part of the 20th century. Sharma et al. (2000b) also noticed a decline in minimum temperature for several stations in Nepal.

Studies by Kumar et al. (1994), Yadav et al. (2004), Arora et al. (2005), Fowler and Archer (2006), Bhutiyani et al. (2007), Das et al. (2007) and Pal and Al-Tabbaa (2010) on the Indian subcontinent suggest that an increasing diurnal temperature range causes the warming of maximum temperature. In contrast, studies by Duan et al. (2006), Liu et al. (2006) and You et al. (2008) on the Tibetan Plateau have concluded that a decreasing diurnal temperature range due to anthropogenic climate change causes the prominent warming of minimum temperature. In both cases, the studies agree that in recent decades average warming has clearly increased. In this study, analyses of temperature anomaly in figure 3 and CUSUM charts in figure 5 at the mountain stations also show consistent results related to larger and obvious average warming in the last decade of the time series.

Many studies (e.g., Liu and Chen 2000; Duan et al. 2006; Kumar et al. 2006; Liu et al. 2006; Bhutiyani et al. 2007; You et al. 2008) suggest that increasing anthropogenic GHGs are responsible for warming on the Indian subcontinent and the Tibetan Plateau in recent decades. It is to be noted 

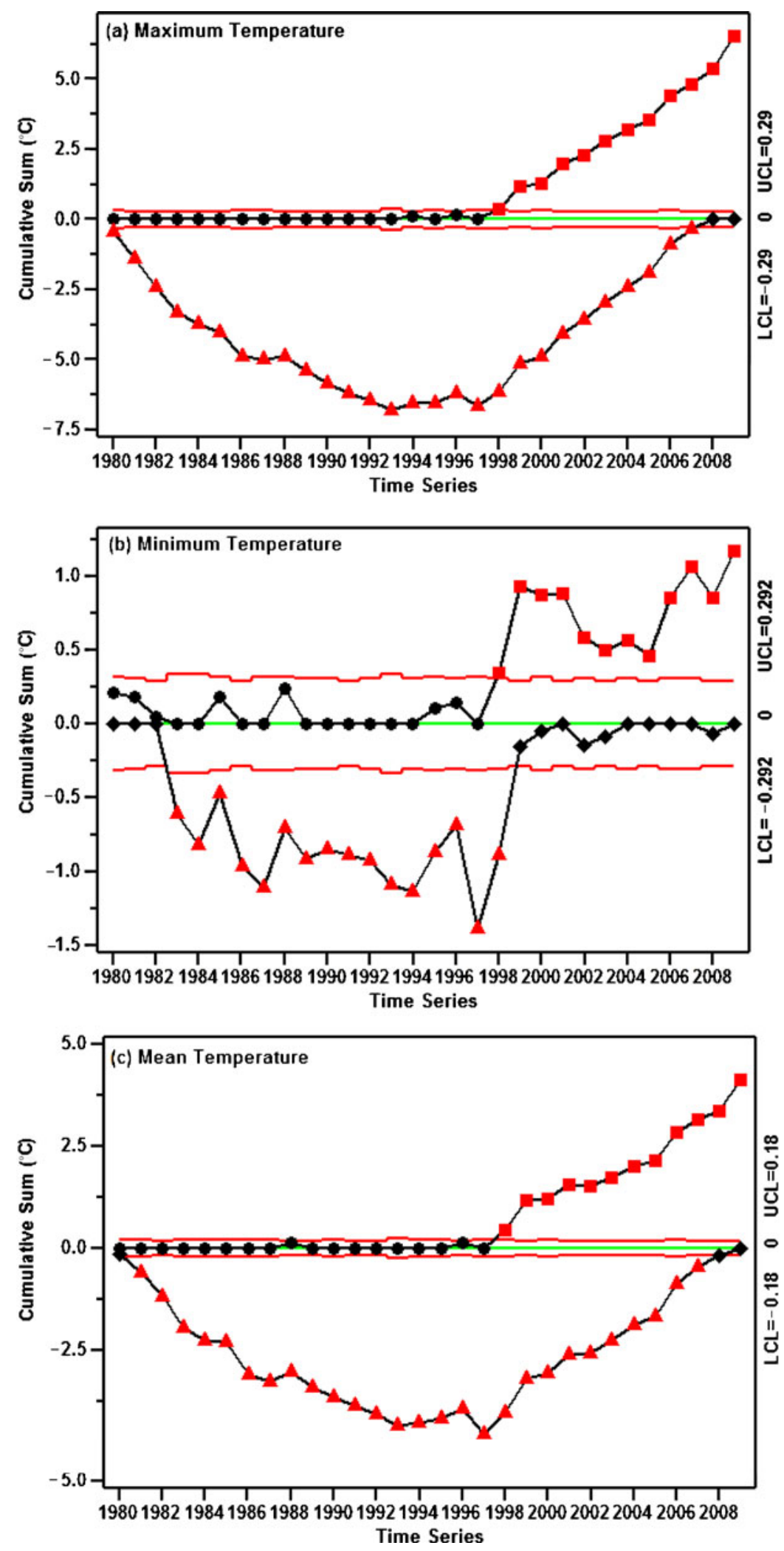

Figure 5. The representative charts of the cumulative sum of deviations of the observed years of all mountain stations (a) maximum, (b) minimum and (c) average temperatures.

that the rate of growth of GHG emissions, particularly carbon dioxide, was much higher during the period 1995-2004 than during the previous period of 1970-1994 (IPCC 2007). These results indicate that anthropogenic emissions are possibly linked to recent warming. However, similar to the western 
Himalayas, India and the Upper Indus Basin, the mountain stations on the southern slope of the central Himalayas exhibit variable warming. Previous studies (e.g., Kumar et al. 1994; Yadav et al. 2004; Fowler and Archer 2006; Das et al. 2007) in this region suggest that local factors such as deforestation and land degradation are responsible for the observed differences.

According to the Central Bureau of Statistics, Nepal (CBS 2008), the highest rate of forest degradation $(2.3 \% / y)$ is found in mountainous as opposed to lower elevation regions of Nepal. Statistics from the same source also indicate that urban area growth is increasing in mountainous regions. In 1981, urban area coverage in hilly and mountain regions was $3 \%$; later in 2001, coverage reached $20 \%$. This scenario illustrates the connection between temperature variability and local factors such as deforestation and land degradation. However, without more comprehensive studies, it is very difficult to quantify this relationship. In this study, we limited the investigation to the variability of temperature trends with respect of topography, as further discussed in subsection 3.5.

\subsection{Possible contributory factors for variation of trends at mountain stations}

A recent study by You et al. (2010) on the Tibetan Plateau suggests that topography plays a factor in temperature trend magnitudes. The climatic feature in figure 3 shows that the interannual fluctuation of temperature is more variable for the minimum temperature (figure 3c) than that of the maximum temperature (figure 3a). The Pearson product moment correlation coefficient of interannual variation of temperature between the stations (table 4) supports this result. The correlation coefficient is greater for the maximum temperature, ranging from 0.43 to 0.90 (table 4). In contrast, the majority of the stations do not show any significant relationship with each other for the interannual fluctuation of minimum temperature. Some stations also exhibit negative relationship (table 4). These results suggest that the interannual fluctuation of minimum temperature is varied and can be affected by topography.

The stations used in our study are located in various topographic conditions and locations: valley, hilltop, north-facing and south-facing slopes (table 1). The largest number of stations are located in valleys. Generally, humidity, cloudiness, wind velocity and the orientation of the valleys as well as drainage patterns of cold airflow from hilltops and slopes may influence the minimum temperature (Gouvas et al. 2011). In addition, valleys are typically influenced by an inversion effect associated with cold air pooling during the night. In this study, the valley stations were generally consistent in maximum temperature warming, while minimum temperatures were more variable with positive, negative or no change observed.

Among the valley stations, the two stations Khumaltar and Godavari - are located in the urban area of Kathmandu valley, the densely populated capital city of Nepal. The average warming at these two stations were $0.53^{\circ} \mathrm{C} /$ decade (Khumaltar) and $0.46^{\circ} \mathrm{C} /$ decade (Godavari), respectively. Results from the $\mathrm{M}-\mathrm{K}$ trend test for average temperature for these two stations are statistically significant. The greater magnitude warming for these two stations was likely caused by a strong urban effect. Sharma et al. (2000a) suggested that local anthropogenic sources heavily influence the urban air in Kathmandu and warming is enhanced by its location at the bottom of a basin surrounded by mountains (Shrestha et al. 1999).

Bhutiyani et al. (2007) and Ueno and Aryal (2008) suggested that the dissimilarity in physiographic characteristics, local climatic conditions and monsoon circulation might also influence the unevenly distributed temperature trends. The large difference in rainfall amount $(5086.97 \mathrm{~mm})$ and average temperature $\left(4.93^{\circ} \mathrm{C}\right)$ between the Lumle and Thakmarpha stations, with only $826 \mathrm{~m}$ of elevation difference, provide a clear illustration of the spatial variability of temperature and rainfall that can occur within a relatively small distance (table 1). These two stations also have contrasting minimum temperature trends (table 2) and are located within different climatic regimes. Lumle is located on the windward (high rainfall zone) and Thakmarpha is located on the leeward (rainfall shadow zone) side. In the rainfall regions, monsoon moisture regulates the temperature, while this effect is lessened in the more arid rain shadow region with less moisture (Bhutiyani et al. 2007). Generally, rainfall and cloud cover reduce the diurnal temperature range.

In addition, Das et al. (2007) pointed out that heat exchange on slopes of the Himalayas may lead to large fluctuations in the minimum temperatures observed in northern India. In our study, the aspect of seven stations also differs. The two stations Dadeldhura and Okhaldhunga, where the maximum temperature warming is greatest, are located on hilltops. The four stations Silghadi Doti, Taplejung, Lumle and Kakani are located on southfacing slopes. Another station, Nagarkot, is located on a north-facing slope. It is also noted that most of the stations located on slopes show a positive minimum temperature trend, with the exception of Silghadi Doti. However, the magnitude of increase is lower as compared to maximum temperature, with the exception of Kakani station (table 2). The higher increasing trend of minimum temperature at 
Table 4. Pearson product moment correlation coefficient of interannual variation of maximum $\left(T_{\max }\right)$, minimum $\left(T_{\min }\right)$ and average $\left(T_{\text {avg }}\right)$ temperature between the stations.

\begin{tabular}{|c|c|c|c|c|c|c|c|c|c|c|c|c|}
\hline Station & 2 & 3 & 4 & 5 & 6 & 7 & 8 & 9 & 10 & 11 & 12 & 13 \\
\hline $1-T_{\max }$ & $0.71^{*}$ & $0.80^{*}$ & $0.77^{*}$ & $0.81^{*}$ & $0.83^{*}$ & $0.79^{*}$ & $0.88^{*}$ & $0.71^{*}$ & $0.54^{* *}$ & 0.33 & $0.86^{*}$ & $0.82^{*}$ \\
\hline$T_{\min }$ & $0.61^{*}$ & $0.75^{*}$ & 0.15 & $0.42^{* * *}$ & $0.59^{* *}$ & $0.64^{*}$ & 0.19 & 0.33 & $0.73^{*}$ & $0.46^{* * *}$ & $0.76^{*}$ & -0.22 \\
\hline$T_{\text {avg }}$ & $0.83^{*}$ & $0.88^{*}$ & 0.25 & $0.81 *$ & $0.88^{*}$ & $0.77^{*}$ & $0.94^{*}$ & $0.74^{*}$ & $0.87^{*}$ & $0.49 * * *$ & $0.88^{*}$ & $0.55^{* *}$ \\
\hline $2-T_{\max }$ & & $0.86^{*}$ & $0.72^{*}$ & $0.86^{*}$ & $0.77^{*}$ & $0.65^{*}$ & $0.87^{*}$ & $0.65^{*}$ & 0.24 & $0.61^{* *}$ & $0.51^{* * *}$ & $0.64^{* *}$ \\
\hline$T_{\min }$ & & $0.47^{* * *}$ & 0.16 & 0.30 & $0.65^{*}$ & $0.74^{*}$ & $0.59 *$ & $0.56^{* *}$ & 0.35 & $0.59^{* *}$ & $0.57^{* *}$ & 0.04 \\
\hline$T_{\text {avg }}$ & & $0.91^{*}$ & 0.36 & $0.83^{*}$ & $0.74^{*}$ & $0.78^{*}$ & $0.83^{*}$ & $0.60^{* *}$ & $0.84^{*}$ & $0.71^{*}$ & $0.80^{*}$ & $0.54^{* * *}$ \\
\hline $3-T_{\max }$ & & & $0.72^{*}$ & $0.80^{*}$ & $0.77^{*}$ & $0.75^{*}$ & $0.84^{*}$ & $0.81^{*}$ & 0.37 & $0.61^{* *}$ & $0.63^{* *}$ & $0.51^{* * *}$ \\
\hline$T_{\min }$ & & & -0.28 & 0.35 & $0.61^{* *}$ & $0.49^{* *}$ & 0.14 & 0.37 & $0.73^{*}$ & $0.47^{* * *}$ & $0.86^{*}$ & -0.40 \\
\hline$T_{\text {avg }}$ & & & -0.02 & $0.85^{*}$ & $0.76^{*}$ & $0.86^{*}$ & $0.90^{*}$ & $0.66^{*}$ & $0.87^{*}$ & $0.53^{* *}$ & $0.84^{*}$ & 0.42 \\
\hline $4-T_{\max }$ & & & & $0.70^{*}$ & $0.64^{*}$ & $0.55^{* *}$ & $0.75^{*}$ & $0.60 * *$ & 0.21 & $0.57^{* *}$ & $0.57^{* *}$ & $0.71^{*}$ \\
\hline$T_{\min }$ & & & & 0.22 & 0.11 & 0.05 & $0.41^{* * *}$ & $0.49 * * *$ & -0.23 & 0.21 & -0.04 & 0.09 \\
\hline$T_{\text {avg }}$ & & & & 0.38 & 0.28 & 0.03 & 0.31 & 0.22 & 0.29 & 0.085 & 0.13 & -0.03 \\
\hline $5-T_{\max }$ & & & & & 0.90* & $0.64^{*}$ & $0.92^{*}$ & $0.73^{*}$ & 0.29 & 0.39 & $0.64^{*}$ & $0.80^{*}$ \\
\hline$T_{\min }$ & & & & & -0.01 & $0.46^{* * *}$ & $0.68^{*}$ & 0.43 & 0.36 & 0.32 & 0.20 & 0.04 \\
\hline$T_{\text {avg }}$ & & & & & $0.78^{*}$ & $0.67^{*}$ & $0.87^{*}$ & $0.61^{* *}$ & $0.87^{*}$ & $0.58^{* *}$ & $0.67^{*}$ & 0.44 \\
\hline $6-T_{\max }$ & & & & & & $0.72^{*}$ & $0.91^{*}$ & $0.84^{*}$ & $0.55^{* *}$ & 0.22 & $0.84^{*}$ & $0.86^{*}$ \\
\hline$T_{\min }$ & & & & & & 0.37 & 0.40 & 0.33 & 0.41 & $0.52^{* * *}$ & $0.63^{* * *}$ & $-0.46^{* * *}$ \\
\hline$T_{\text {avg }}$ & & & & & & $0.80^{*}$ & $0.91^{*}$ & $0.69^{*}$ & $0.73^{*}$ & 0.34 & $0.89^{*}$ & $0.56^{* * *}$ \\
\hline $7-T_{\max }$ & & & & & & & $0.76^{*}$ & $0.56^{* *}$ & $0.56^{* *}$ & 0.12 & $0.77^{*}$ & $0.73^{*}$ \\
\hline$T_{\min }$ & & & & & & & 0.35 & 0.30 & $0.51^{*}$ & $0.45^{* * *}$ & $0.53^{* *}$ & 0.09 \\
\hline$T_{\text {avg }}$ & & & & & & & $0.90^{*}$ & $0.75^{*}$ & $0.75^{*}$ & $0.45 * * *$ & $0.87^{*}$ & $0.58^{* *}$ \\
\hline $8-T_{\max }$ & & & & & & & & $0.73^{*}$ & $0.43^{* * *}$ & 0.38 & $0.84^{*}$ & $0.82^{*}$ \\
\hline$T_{\min }$ & & & & & & & & $0.64^{*}$ & 0.00 & 0.31 & 0.12 & 0.11 \\
\hline$T_{\text {avg }}$ & & & & & & & & $0.78^{*}$ & $0.84^{*}$ & $0.48^{* * *}$ & $0.93^{*}$ & $0.46^{* * *}$ \\
\hline $9-T_{\max }$ & & & & & & & & & $0.46^{* * *}$ & $0.50 * * *$ & $0.77^{*}$ & $0.68^{*}$ \\
\hline$T_{\min }$ & & & & & & & & & 0.08 & 0.34 & $0.49 * * *$ & -0.16 \\
\hline$T_{\text {avg }}$ & & & & & & & & & $0.79^{*}$ & 0.40 & $0.79^{*}$ & $0.60^{* *}$ \\
\hline $10-T_{\max }$ & & & & & & & & & & -0.041 & $0.60^{* *}$ & $0.50^{* * *}$ \\
\hline$T_{\min }$ & & & & & & & & & & 0.34 & $0.63^{*}$ & -0.17 \\
\hline$T_{\text {avg }}$ & & & & & & & & & & $0.61^{*}$ & $0.76^{*}$ & $0.46^{* * *}$ \\
\hline $11-T_{\max }$ & & & & & & & & & & & 0.05 & 0.17 \\
\hline$T_{\min }$ & & & & & & & & & & & 0.35 & -0.12 \\
\hline$T_{\mathrm{avg}}$ & & & & & & & & & & & 0.37 & $0.56^{* *}$ \\
\hline $12-T_{\max }$ & & & & & & & & & & & & $0.86^{*}$ \\
\hline$T_{\min }$ & & & & & & & & & & & & -0.33 \\
\hline$T_{\text {avg }}$ & & & & & & & & & & & & $0.61^{* *}$ \\
\hline
\end{tabular}

Note: The significance level $*=0.001, * *=0.01$ and $* * *=0.05 .1=$ Chainpur, $2=$ Okhaldhunga, $3=$ Khumaltar, $4=$ Silghadi Doti, $5=$ Godavari, $6=$ Taplejung, $7=$ Lumle, $8=$ Dadeldhura, $9=$ Jiri, 10=Kakani, 11=Nagarkot, 12=Jumla, 13=Thakmarpha. Bold (minimum temperature) and bold italics (maximum temperature) indicate that the relationship is not statistically significant.

Kakani, may be associated with the urban effect, as this station is a mountain station directly adjacent to the Kathmandu valley.

\section{Conclusions}

This study presents the recent changes of surface air temperature across 13 mountain stations in Nepal. These stations are located within various topographic settings (e.g., valley, hilltop, southfacing and north-facing slopes) and range in elevation from 1304 to $2566 \mathrm{~m}$ above sea level. Using a 30-year time series from 1980 to 2009, annual patterns of average, maximum and minimum temperature trends were studied and compared with previous studies in the surrounding regions. Possible causes related to the observed variation in temperature trends and the thermal regime shift across the mountain region were also discussed. 
Trend analyses revealed a statistically significant average warming for a majority of the mountain stations. The largest magnitude of warming is observed for maximum temperatures, while minimum temperature trends show greater variability among the stations (e.g., increasing, decreasing or no change). This result is consistent with previous studies from parts of the Indian subcontinent, the Himalayan region and the Upper Indus Basin. In those studies, increase in maximum temperature is more prominent than that of minimum temperature. However, our result differs from studies on the Tibetan Plateau, which show that the warming at minimum temperature is more prominent than that of maximum temperature. These asymmetric patterns of daily temperature changes and decreasing diurnal temperature range on the Tibetan Plateau have been considered as signals of anthropogenic climate change.

Analyses of the anomaly and CUSUM of the temperature data from the southern slope of the central Himalayas suggest enhanced warming during the last decades of the time series data. A sharp regime shift is clearly observed, particularly for the maximum and average temperatures from 1997 to 2009. Previous long-term temperature data analyses from the western Himalayas and the Tibetan Plateau also found similar warming in recent decades, attributed mainly to the increase of anthropogenic GHGs. Thus, results indicate that anthropogenic emissions may possibly be enhancing average warming of the recent decades. However, similar to the western Himalayas and the Upper Indus Basin, the mountain stations on the southern slope of the central Himalayas are showing variable temperature trends, particularly for minimum temperature, which may be due to differences in topography and the microclimatic regime of the observed stations.

In this study, a large number of valley stations exhibit generally consistent warming for maximum temperature, although minimum temperature shows greater variability. Humidity, cloudiness, wind velocity, orientation of the valley as well as the drainage pattern of cold airflow from hilltops and slopes may influence minimum temperature. In addition, the aspect of each location may also cause interannual fluctuation of minimum temperature. Thus, different topographic settings may influence interannual fluctuations and variability of minimum temperature trends.

\section{Acknowledgements}

The National Natural Science Foundation of China (Grant Nos. 41190081, 40830638 and 40810019001) and the Chinese Academy of Sciences Third Pole
Environment Program (GJHZ 0906) supported this study. The authors thank the Department of Hydrology and Meteorology, Government of Nepal for providing the data. They also thank Betsy Armstrong, Meri and D R Joswiak for the editing of the manuscript.

\section{Appendix}

\section{Grubbs method}

Grubb's test is based on normal distribution of the data series. In this test, we have two hypotheses: Null-hypothesis $\left(\mathrm{H}_{0}\right)$ and alternative hypothesis $\left(\mathrm{H}_{1}\right)$

$\mathrm{H}_{0}$ : There are no outliers in the dataset.

$\mathrm{H}_{1}$ : There is at least one outlier in the dataset.

The general formula for Grubb's test is followed:

$$
G=\frac{\left|X_{i}-\bar{X}\right|}{\sigma},
$$

where $X_{i}=$ element of the dataset, $\bar{X}=$ mean of the dataset and $\sigma=$ standard deviation of the dataset. The calculated value of parameter $G$ is compared with the critical value for Grubb's test. When the calculated value is higher or lower than the critical value $C$, then the value can be accepted as an outlier. The critical value of the Grubbs' test is calculated in equation (4)

$$
C=\frac{(n-1)}{\sqrt{n}} \sqrt{\frac{t_{\left(\frac{\alpha}{2 n}, n-2\right)}^{2}}{n-2+t_{\left(\frac{\alpha}{2 n}, n-2\right)}^{2}}},
$$

where $t_{\left(\frac{\alpha}{2 n}, n-2\right)}$ denotes the critical value of the $t$ distribution with $(n-2)$ degrees of freedom and a significance level of $\alpha / 2 n$. If $G \geq C$, then the suspected value is confirmed as an outlier (Grubbs 1950).

\section{References}

Adhikari S and Huybrechts P 2009 Numerical modeling of historical front variations and the 21st-century evolution of glacier AX010, Nepal Himalaya; Ann. Glaciol. 50(52) $27-34$.

Arora M, Goel N K and Singh P 2005 Evaluation of temperature trends over India; Hydrol. Sci. J. 50 81-93.

Baidya S K, Shrestha M L and Sheikh M M 2008 Trends in daily climatic extremes of temperature and precipitation in Nepal; Nepal J. Hydrol. Meteorol. 5(1) 38-50.

Barry R G 2002 Mountain climate change and cryosphere responses: A review; World Mountain Symposium 2001, Bern, Switzerland.

Bhutiyani M R, Kale V S and Pawar N J 2007 Long term trends in maximum, minimum and mean annual temperatures across the northwestern Himalaya during the twentieth century; Clim. Change 85 159-177. 
CBS 2008 Environment Statistics of Nepal, 2008, Published by National Planning Commission Secretariat, Central Bureau of Statistics (CBS), Government of Nepal.

Chen A and Chen Y K 2007 Design of EWMA and CUSUM control charts subject to random shift sizes and quality impacts; IIE Trans. 39 1127-1141, doi: 10.1080/ 07408170701315321.

Das S K, Jenamani R K, Kalsi S R and Panda S K 2007 Some evidence of climate change in twentieth-century India; Clim. Change 85 299-321, doi: 10.1007/s10584-007-9305-9.

Diaz H F and Bradley R S 1997 Temperature variations during the last century at high elevation sites; Clim. Change 36 253-279, doi: 10.1023/A:1005335731187.

Duan A, Wu G, Zhang Q and Liu Y 2006 New proofs of the recent climate warming over the Tibetan Plateau as a result of the increasing greenhouse gases emissions; Chin. Sci. Bull. 51(11) 1396-1400, doi: 10.1007/s11434-006-1396-6.

Easterling D R, Horton B, Jones P D, Peterson T C, Karl T R, Parker D E, Salinger M J, Razuvayev V, Plummer N, Jamason P and Folland C K 1997 Maximum and minimum temperature trends for the globe; Science $277364-367$.

Fowler H J and Archer D R 2006 Conflicting signals of climatic change in the Upper Indus Basin; J. Clim. 19 4276-4293.

Fujita K, Thompson L G, Ageta Y, Yasunari T, Kajikawa Y, Sakai A and Takeuchi N 2006 Thirty-year history of glacier melting in the Nepal Himalayas; J. Geogr. Res. 111 D03109, doi: 10.1029/2005JD005894.

Gouvas M A, Sakellariou N K and Kambezidis H D 2011 Estimation of the monthly and annual mean maximum and mean minimum air temperature values in Greece; Meteorol. Atmos. Phys. 110 143-149.

Grubbs F E 1950 Sample criteria for testing outlying observations; Ann. Math. Stat. 21 27-58.

Grubbs F E 1969 Procedures for detecting outlying observations in samples; Technometrics 11(1) 13-14.

Hansen J, Sato M, Ruedy R, Lo K, David W L and Martin M-E 2006 Global temperature change; PNAS 103(39) 14,288-14,293.

Hodges R J, Addo S and Birkinshaw L 2003 Can observation of climate variables be used to predict the flight dispersal rates of Prostephanus truncates?; Agric. Forest Entomol. 5 123-135.

IPCC Climate Change 2007 Synthesis Report; Summary for policy makers from http://www.ipcc.ch/pdf/assessmentreport/ar4/syr/ar4_syr_spm.pdf.

Kadota T and Ageta Y 1992 On the relation between climate and retreat of Glacier A X010 in the Nepal Himalaya from 1978 to $1989 ;$ Bull. Glacier Res. $101-10$.

Kadota T, Fujita K, Seko K, Kayastha R B and Ageta Y 1997 Monitoring and prediction of shrinkage of a small glacier in the Nepal Himalaya; Ann. Glaciol. 24 90-94.

Kothawale D R and Kumar K R 2005 On the recent changes in surface temperature trends over India; Geophys. Res. Lett. 32 L18714, doi: 10.1029/2005GL023528.

Kumar K R, Kumar K K and Pant G B 1994 Diurnal asymmetry of surface temperature trends over India; Geophys. Res. Lett. 21 677-680.

Kumar K R, Sahai A K, Kumar K K, Patwardhan S K, Mishra P K, Revadekar J V, Kamala K and Pant G B 2006 High-resolution climate change scenarios for India for the 21st century; Curr. Sci. 90(3) 334-345.

Liu X and Chen B 2000 Climatic warming in the Tibetan Plateau during recent decades; Int. J. Climatol. 20 1729-1742.
Liu X, Yin Z-Y, Shao X and Qin N 2006 Temporal trends and variability of daily maximum and minimum extreme temperature events, and growing season length over the eastern and central Tibetan Plateau during 1961-2003; J. Geophys. Res. 111 D19109, doi: 10.1029/2005JD006915.

Mansell M G 1997 The effect of climate change on rainfall trends and flooding risk in the west of Scotland; Nordic Hydrol. 28 37-50.

Naito N, Ageta Y, Nakawo M, Waddington E D, Raymond C F and Conway H 2001 Response sensitivities of a summer-accumulation type glacier to climate changes indicated with a glacier fluctuation model; Bull. Glaciol. Res. 18 1-8.

Page E S 1961 Cumulative sum charts; Technometrics 3(1) 1-9.

Pal I and Al-Tabbaa A 2010 Long-term changes and variability of monthly extreme temperatures in India; Theor. Appl. Climatol. 100 45-46, doi: 10.1007/s00704-009-0167.

Shapiro G I, Aleynik D L and Mee L D 2010 Long term trends in the sea surface temperature of the Black Sea; Ocean Sci. 6 491-501, doi: 10.5194/os-6-491-2010.

Sharma U K, Kajii Y and Akimoto H 2000a Characterization of NMHCs in downtown urban center Kathmandu and rural site Nagarkot in Nepal; Atmos. Environ. 34(20) 3297-3307.

Sharma K P, Moore B and Vorosmarty C J 2000b Anthropogenic, climatic, and hydrologic trends in the Koshi Basin, Himalaya; Clim. Change 47 141-165.

Shrestha A B and Aryal R 2010 Climate Change in Nepal and its impact on Himalayan Glacier; Reg. Environ. Change 11(1) 65-77, doi: 10.1007/s10113-010-0174-9.

Shrestha A B, Wake C P, Mayewski P A and Dibb J E 1999 Maximum temperature trends in the Himalaya and its vicinity: An analysis based on temperature records from Nepal for the period 1971-94; J. Clim. 12 2775-2786.

Tam D 2009 A theoretical analysis of cumulative sum slope (CUSUM-Slope) statistic for detecting signal onset (begin) and offset (end) trends from background noise level; Open Stat. Probab. J. 1 43-51.

Ueno K and Aryal R 2008 Impact of tropical convective activity on monthly temperature variability during nonmonsoon season in the Nepal Himalayas; J. Geophys. Res. 113 D18112, doi: 10/.1029/2007JD009524.

Yadav R R, Park W K, Singh J and Dubey B 2004 Do the western Himalayas defy global warming?; Geophys. Res. Lett. 31 L17201, doi: 10.1029/2004GL020201.

Yao T, Pu J, Lu A, Wang Y and Yu W 2007a Recent glacial retreat and its impact on hydrological process on the Tibetan Plateau, China and surrounding regions; Arctic Antarc. Alpine Res. 39(4) 642-650.

Yao T, Duan K, Thompson L G, Wang N, Tian L, Xu B, Wang $\mathrm{Y}$ and $\mathrm{Yu}$ W 2007b Temperature variations over the past millennium on the Tibetan Plateau revealed by four ice cores; Ann. Glaciol. 46 362-366.

You Q, Kang S, Aguilar E and Yan Y 2008 Changes in daily climate extremes in the eastern and central Tibetan Plateau during 1961 to 2005; J. Geophys. Res. 113 D07101, doi: 10.1029/2007JD009389.

You Q, Kang S, Pepin N, Flügel W-A, Yan Y, Behrawan $\mathrm{H}$ and Huang J 2010 Relationship between temperature trend magnitude, elevation and mean temperature in the Tibetan Plateau from homogenized surface stations and reanalysis data; Global Planet. Change 71 124-133.

Zhang Q, Kang S and Yan Y 2006 Characteristics of spatial and temporal variations of monthly mean surface air temperature over Qinghai-Tibet Plateau; Chin. Geogr. Sci. 16(4) $351-358$. 